\title{
GEOTHERMAL ENERGY DEVELOPMENT
}

\author{
PAUL KRUger
}

NOVEMBER, 1975

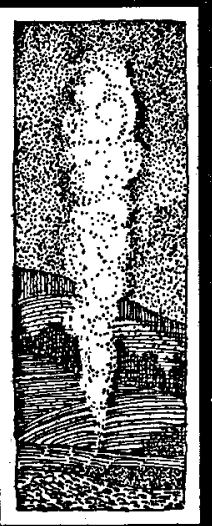

Stanford Geothermal Program INTERDISCIPLINARY RESEARCH IN ENGINEERING AND EARTH SCIENCES Stanford University, Stanford, California 


\section{DISCLAIMER}

This report was prepared as an account of work sponsored by an agency of the United States Government. Neither the United States Government nor any agency Thereof, nor any of their employees, makes any warranty, express or implied, or assumes any legal liability or responsibility for the accuracy, completeness, or usefulness of any information, apparatus, product, or process disclosed, or represents that its use would not infringe privately owned rights. Reference herein to any specific commercial product, process, or service by trade name, trademark, manufacturer, or otherwise does not necessarily constitute or imply its endorsement, recommendation, or favoring by the United States Government or any agency thereof. The views and opinions of authors expressed herein do not necessarily state or reflect those of the United States Government or any agency thereof. 


\section{DISCLAIMER}

Portions of this document may be illegible in electronic image products. Images are produced from the best available original document. 


\title{
GEOTHERMAL ENERGY DEVELOPMENT *
}

\author{
Paul Kruger \\ Civil Engineering Department \\ Stanford University \\ Stanford, California
}

\author{
Manuscript \\ Symposium on Environment and Energy Conservation \\ Denver, Colorado
}

November $3-6,1975$

*based on reports prepared during Leave of Absence 1974-75 with the National Science Foundation and the Energy Research and Development Administration. 


\section{INTRODUCTION}

The Nation has embarked on an aggressive program to develop its indigenous resources of geothermal energy. For more than a decade, geothermal energy has been heralded as one of the more promising forms of energy alternate to oil and gas for electric power generation, but during the last fifteen years, the total capacity in the U.S. has reached 502 MWe, about half the size of a single modern nuclear power plant. And yet, the United States, especially its western and Gulf coast states, is believed to possess a vast resource base of geothermal heat at depths up to 3 to $10 \mathrm{~km}$. Many estimates of these potential resources suitable for the production of electric power have been published and they range over a spectrum of more than a factor of 100 . This variation suggests that the potential is essentially unknown.

Table 1 gives a range of published forecasts for the year 1985 and the equivalent potential in number of 1000 MWe power plants and in oil consumption in millions of barrels per day. In view of the estimated construction of about 200 to 250 nuclear power reactors by $1985-90$, the pessimistic forecasts clearly show that the contribution of geothermal energy to the Nation's energy supply may indeed be smal1. The optimistic forecasts represent more than $15 \%$ of the total electric power requirements estimated for the year 1985. The Task Force for Geothermal Energy, in the Federal Energy Aministration Project Independence Blueprint report of November 1974, established a national goal for 1985 of 20,000 to $30,000 \mathrm{MWe}$, the latter value representing an equivalent energy supply of one million barrels of oil per day. This goal was 
TABLE 1

FORECASTS AND NATIONAL GOAL FOR DEVELOPMENT OF U.S, GEOTHERMAL RESOURCES

\begin{tabular}{lcc} 
Pessimistic & NATIONAL GOAL & OPTIMISTIC \\
ForECAstS & 1985 & ForeCAstS \\
\hline
\end{tabular}

ELECTRIC AND THERMAL

Energy CAPACITY (MW) $2000-4000 \quad 20,000-30,000 \quad 182,000-400,000$

EQUiVALENT IN NUCLEAR REACTORS

(No. 1000 MWE UNITS)

$2-4$

$20-30$

$182-400$

Equivalent CONSUMPTION OF OIL $\left(10^{6}\right.$ BBL/DAY $)$

$0.07-0.14$

$0.7-1$

$6-14$ 
clearly a compromise between what is worth a national effort and what might be realistically achieved. The potential for adding or replacing the equivalent of some 25 nuclear power plants or for conserving one million barrels of oil per day should be an adequate incentive for the Nation to accelerate the development of a viable geothermal industry. A puzzling enigma appears. If the potential resource base of geothermal energy is so vast, why has significant utilization not occurred? The entire U.S. production of electric power from geothermal resources occurs at one location, the Geysers in California, where over a 15-year period starting in 1960, generating capacity has grown from 12 MW supplied by Unit No. 1 to the total of 502 MW attained with the startup of the 106-MW Unit No. 11 in May 1975. The Geysers is the largest geothermal electricity generating station in the world. The entire worldwide capacity of electric power generation by geothermal resources is slightly more than $1000 \mathrm{MW}$, the equivalent of the capacity of a single modern nuclear power plant.

Utilization of geothermal fluids for thermal energy in the U.S. is almost negligible. And yet throughout the country, fossil fuels are consumed in large quantities to boil water for heating and electric power generation, both at very low thermal efficiency. Some countries already use geothermal fluids for its thermal energy, notably Iceland, where municipal heating is an important utilization. Several countries, responding to increased public awareness that future supply of fossil fuel may be very limited, are examining the potential use of indigenous thermal waters for industrial and municipal heating.

How is this enigma to be solved; how is the United States (and other countries) endowed with potentially-bountiful geothermal resources 
going to develop these natural resources as a significant contribution to its energy supply? The attainment of a national goal to contribute an equivalent of one million barrels of oil per day from geothermal resources clearly requires accelerated development of a geothermal industry capable of providing 20,000 to $30,000 \mathrm{MW}$ of electric power and thermal energy in the next ten to fifteen years. And this objective will require a national effort to accelerate and coordinate development in three parallel tasks: (1) the discovery, proving, and extraction of geothermal resources to provide a significant supply of hydrothermal fluids for direct utilization and to produce more than $5 \times 10^{12} \mathrm{kWh}$ of electricity over the amortization period of the investment in resource development and power plant construction; (2) the technology to convert the resources as found in its various natural forms and qualities into electricity, and (3) the removal of unnecessary institutional constraints to the rapid development of a cost-effective and environmentally-acceptable industry.

A major factor which helps create the enigma of vast resource base and little utilization is the variability of geothermal resources. The geothermal energy cycle, although simple compared to other alternate energy sources, is actually complex in that geothermal resources occur in many types of geologic, thermodynamic, hydrodynamic, and chemical quality. As a result, the major problems in the energy cycle vary by type of resource. Table 2 lists the key aspects of the cycle from exploration to utilization that must be evaluated for each type of resource.

Several general reviews of the state of the art of geothermal energy resources and technology are listed in the Bibliography. One is 


\section{TABLE 2}

PROBLEM AREAS IN THE DEVELOPMENT OF THE GEOTHERMAL ENERGY CYCLE

VARIABILITY OF GEOTHERMAL RESOURCES

LOCATION OF SUBSURface RESERVOIRS

Reservoir EVALUATION

EXTRACTION TECHNOLOGY

Conversion TeChNOLOGY

Potential for Multiple Utilization

ENVIRONMENTAL IMPACT CONTROL

Legal and Institutional Constraints 
the proceedings of the 1970 United Nations symposium on the development and utilization of geothermal resources. Another is the 1973 compilation of an Ad Hoc Working Group convened by UNESCO. A general introduction to geothermal energy is the proceedings of the American Nuclear Society conference on geothermal resources, production, and stimulation held in 1972. Among other compilations of papers on geothermal energy are the proceedings of the second and third All-Union conferences on geothermal energy organized by the Scientific Council for Geothermal Investigations of the USSR Academy of Sciences. Translations of these proceedings are not generally available, but much of the technical content is given in the Soviet papers of volume 2 of the United Nations Symposium and in the ARPA reviews of Soviet literature in geothermal energy. The proceedings of the Second United Nations Symposium held in San Francisco in May 1975, adds another major contribution to the 1iterature of geothermal energy.

\section{GEOTHERMAL RESOURCES}

The upper $10 \mathrm{~km}$ of the earth's crust may contain more than $3 \times 10^{26}$ cal of heat, a resource base readily classified as vast. However, much of this energy is too diffuse to be exploitable as an energy source. Geothermal resources may be defined as localized deposits of geothermal heat concentrated at attainable depths, in adequate volumes, and at temperatures sufficient for commercial exploitation.

The only geothermal resources presently used for electric power generation are high-quality hydrothermal convective systems which contain high-enthalpy geofluids suitable for transferring the geothermal heat to the surface for direct use in low-efficiency steam turbines. 
Unfortunately such resources have been discovered at only a few places on earth. More than $75 \%$ of the world's geothermal electric power capacity results from vapor-dominated hydrothermal systems which produce dry or super-heated steam for direct conversion. The remaining capacity results from high-temperature, low-salinity, water-dominațed hydrothermal systems in which the geofluids are flashed on production, and only the separated steam is used for electric power generation. The liquid fraction is either wasted or reinjected into the ground. These systems are commercially less desirable because only a small fraction of the water flashes to steam, thermal efficiencies are 1ow, and plant operational problems are more severe.

Liquid dominated hydrothermal systems are expected to be many times more abundant than vapor-dominated hydrothermal systems. Moderate-tohigh salinity hydrothermal resources may be more abundant than low salinity resources. And other types of geothermal resources, such as hypersaline brines, geopressured fluids, volcanic and magmatic deposits, and impermeable hot-rock massives, which are not yet commercially exploitable, may be even more abundant than the currently exploited hydrothermal resources. Thus the answer to the utilization enigma may lie not so much with the magnitude of the resource base, but more with the ability to locate suitable concentrated deposits of geothermal heat and the technology to extract the energy in quantities which are economically and enviromentally feasible.

Although estimates of the geothermal resource base are avallable, the magnitude of the potential reserves is not yet well defined. The location of underground deposits of geothermal heat, especially where 
thermal manifestations are not visible at the surface, is a difficult task. Over one million acres of "hot spots," areas of known geothermal energy, were identified as early as 1967 by the U.S. Department of the Interfor in designated Federal lands in five western states as having current potential value as geothermal resources. An additional 86 million acres of land in thirteen states were designated as prospectively valuable for geothermal resources. Since then several other inventories of known geothermal resource areas (KGRA) have been compiled. A current assessment of U.S. geothermal resources has been completed by the U.S, Geological Survey and a summary of the resource base, by resource type, is given in Table 3 .

Exploration for geothermal resources has been undertaken by industry on private lands, and through the Federal Leasing Act of 1970, on Federal lands by competitive and non-competitive leasing under supervision of the Bureau of Land. Management. Although total values are difficult to ascertain, it is estimated that about 100,000 acres on Federal public lands and about 200,000 acres on Federal Indian lands were under lease for geothermal exploration in mid- 1975 .

Resource exploration and assessment of potential reservotrs of geothermal energy are made by the variety of earth science methods 1isted in Table 4. Details of these methods are available in the general references listed in the Introduction. The final phase of geothermal exploration is the drilling of exploratory wells. It is from these wells that data for evaluating the suitability of the resource as a production reservoir are obtained. Major factors in the economics of exploration and production of geothermal fields are the success of 
TABLE 3

SUMMARY OF GEOTHERMAL RESOURCE BASE OF THE UNITED STATES*

Estimated Heat Content $\left(10^{18} \mathrm{CAL}\right)$

IDENTIFIED

POTENTIAL

HYDROTHERMAL CONVECTION SYSTEMS

VAPOR-DOMINATED（STEAM）

HIGH T - HOT WATER $\left(T>150^{\circ} \mathrm{C}\right)$

MOD T - HOT WATER $\left(90^{\circ}-150^{\circ} \mathrm{C}\right)$

TOTAL

HOT IGNEOUS SYSTEMS

MAGMA AND HOT ROCK

GEOPRESSURED BASIN PART OF

REGIONAL CONDUCTIVE SYSTEMS

Total Resource Base

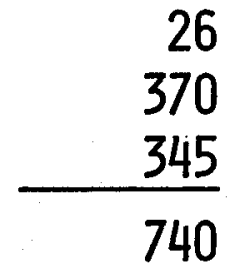

50

1,600

1,400

3,000

25,000

100,000

10,920

44,000

36,660

147,000

*From D. F. White and D. L. Williams, eds., Assessment of GeOtHeRMAL Resources of the UNited StATES - 1975, U. S. Geological SuRVEy Circular 726, 1975. 


\section{TABLE 4 \\ GEOTHERMAL EXPLORATION METHODS}

EXPLORATION SURVEYS

AIRBORNE

Aeromagnetic Survey

THERMAL INFRARED SURVEY

GEOLOGICAL

TECTONICS AND STRATIGRAPHY

ReCent Faulting

Distribution and Age of Volcanic Rocks

Thermal Manifestations

HYDROLOGIC

SURFACE DISCHARGE OF GEOFLUIDS

TeMPERATURE OF Fluids

Chemical Composition of Fluids

GROUNDWATER HYDROLOGY

Meteorology

GEOCHEMICAL

ChloR ide CONCENTRATION

$\mathrm{SiO}_{2}$ CONTENT

NA-K-CA Ratios

ISOTOPIC COMPOSITION OF HYDROGEN AND OXYGEN

GEOPHYSICAL

GEOTHERMAL GRADIENT

HEAT FLOW

ELECTRICAL CONDUCTIVITY

SEISMIC ACTIVITY

EXPLORATION Hole Drilling

Reservoir CHARACTERISTICS

Temperature-Depth Profile

Pressure-Depth Profile

LITHOLOGY AND STRATIGRAPHY

Permeability Log

POROSITY LOG

Fluid Composition 
techniques available for surface exploration of potential resources and exploratory drilling of potential reservoirs. Improvements and novel methods for reducing costs in these two initial phases of the geothermal energy cycle are thus of great importance. In order to achieve the goal of providing an equivalent of one million barrels of oil per day by geothermal resources, it is evident that exploration for geothermal resources, especially hydrothermal, must receive a very high priority by the U.S. energy resource industry.

The magnitude of hydrothermal resources required can be estimated from the following calculation for a 100 MWe generating plant operating with flashed steam of $555 \mathrm{kcal} / \mathrm{kg}(1000 \mathrm{Btu} / \mathrm{lb})$ heat content. The required geofluid production rate for a hot-water system yielding $10 \%$ steam on flashing with a thermal efficiency of 20 percent, would be $7.75 \times 10^{6} \mathrm{~kg} / \mathrm{h}\left(1.7 \times 10^{7} \mathrm{lb} / \mathrm{hr}\right)$. The amortization of the $100 \mathrm{MWe}$ plant over a period of thirty years would require a total production of $2.1 \times 10^{12} \mathrm{~kg}$ hot water, and a mean reservoir porosity of 10 percent would require a geothermial reservoir volume of about $2 \mathrm{~km}^{3}$. At a 50 percent condensation efficiency, the plant would discharge a hot water supply of about $100,000 \mathrm{~m}^{3} / \mathrm{d}\left(2.5 \times 10^{7} \mathrm{gpd}\right)$.

For a national capacity of 20,000 MWe, these values are multiplied by a factor of 200 . Thus reservoirs supporting 200 units of 100 MWe generating plants must be located. These reservoirs will produce about $1.5 \times 10^{9} \mathrm{~kg} / \mathrm{h}$ of hot water. For a mean well production flow rate of $250,000 \mathrm{~kg} / \mathrm{h}$ a total of 6,000 production wells will be needed, and for a mean spacing of $100,000 \mathrm{~m}^{2} /$ we11 (25 acres/we11), a total reservoir area of $6 \times 10^{8} \mathrm{~m}^{2}\left(1.5 \times 10^{5}\right.$ acres $)$ of geothermal resources must be 
found. It is evident that if hydrothermal systems are to provide the nation with 20,000 MWe, very high priority for resource exploration and assessment is indeed required.

\section{UTILIZATION TECHNOLOGY}

Utilization of geothermal energy varies with the quality of available resources. It has been noted that the present geothermal industry has focused on high quality hydrothermal resources. Extraction and conversion technologies for dry-steam reservoirs are sufficiently advanced to be commercially attractive. Conversion technologies for hot-water resources are more complex, and for hot brines, geopressured basins, and hot dry rock formations, they are even more complex; commercial utilization is still further away. Since these latter types of resource hold great promise, technology to exploit them must be developed.

Stimulation of geothermal energy production can be achieved by research and development to (1) increase the modes of resource utilization, (2) Improve energy conversion technology, and (3) provide advanced methods of energy extraction. Increased efficiency in each of these three aspects of the geothermal energy cycle is attainable.

Development of a geothermal field generally involves the geofluid characteristics, steam separation and gathering facilities, turbine and generator equipment, cooling systems, and condensate disposal methods. Such development presupposes that electric power generation is the sole purpose of the field development. It may turn out, however, that for many geothermal reservoirs, non-electric utilization of the resource may make the reservoir economically feasible, with significant conservation of fossil and nuclear fuels. Several modes of utilization of geothermal 
resources are listed in Table 5. Hydrothermal fluids with temperature or enthalpy too low for economic electric power production may be useful for water or mineral sources and for industrial, agricultural, and municipal heating. However, since major interest in geothermal energy is for the production of electric power, combined or total utilization may help make many geothermal reservoirs submarginal in power production alone become economically feasible. The possibility of building a community around a geothermal resource, with municipal heating, an industrial park of process firms requiring hot water and concomitant electric power production appears feasible. Thus, research for methods stimulating geothermal resource utilization in all forms is well warranted.

General methods for producing electricity from geothermal fluids are summarized in Table 6 and are described adequately in the several cited references. The choice of a conversion cycle is generally dependent on the thermodynamic and chemical properties of the geofluid. Present commercial plants utilize low-salinity hydrothermal systems with steam or water at temperatures above about $200^{\circ} \mathrm{C}$ in the single-stage direct steam turbine conversion system. To utilize lower temperature fluids, investigations are underway to develop other conversion systems; among these are multiple-flash low-pressure steam turbines, single and multiple stage binary cycle systems, and hybrid systems combining these two. The binary system appears to be the most promising for utilization of geofluids with temperatures between $100^{\circ} \mathrm{C}$ and $200^{\circ} \mathrm{C}$. However only one experimental facility, the Pauzhetka station in the Kamchatka peninsula of the USSR, has been constructed to date. The binary system most likely to be successful in the U.S. will require a downhole pump to prevent flashing, a heat exchanger which can operate without excessive 


\author{
TABLE 5 \\ UTILIZATION OF GEOTHERMAL ENERGY \\ Electric Power Production \\ DIRECT USE OF DRY STEAM \\ FLASHING OF HOT WATER TO STEAM \\ SURFACE FLASHING \\ IN-SITU FLASHING \\ BINARY AND HYBRID CYCLES \\ INNOVATIVE SINGLE-WELL CONVERTERS \\ Direct Use of Thermal Waters \\ AGRICULTURE \\ AQUICULTURE \\ SPACE HEATING \\ INDUSTRIAL PROCESSING \\ MEDICAL THERAPY \\ BYPRODUCTS \\ Mineral EXTRACTION \\ WATER RESOURCES
}


TABLE 6

TYPES OF GEOTHERMAL POWER PLANTS

\author{
Heat SOURCE Generation Mode \\ DRY STEAM \\ StEAM TURBINE \\ HOT WATER $\left(T>180^{\circ} \mathrm{C}\right)$ \\ Steam TURBine \\ HOT WATER $\left(T<150^{\circ} \mathrm{C}\right)$ \\ BinaRY CyCLE \\ HOT WATER \\ (Moderate Salinity) Hybrid Cycle \\ Hot Brine (Pressurized) Binary Cycle \\ Hot Brine (FLASHED) Impact TURBine \\ HELICAL SCREW EXPANDER \\ BLADELESS TURBINE
}


corrosion and deposition, and a circulation system which allows for reinjection of the geofluids for environmental control purposes.

Several types of downhole pumps are under development, involving design concepts which use (a) in-situ heat to operate a closed steamgenerator-turbine to drive the pump, (b) a high-speed, high-temperature high length-to-diameter electric-motor driven pump, or (c) a hydraulically driven unit with hydraulic power from the surface. Heat exchanger concepts include fluidized sand beds to enhance heat transfer rate and maintain clean surface, and liquid-1iquid systems with direct contact of immiscible fluids, tray-tower contactors, or subcritical or supercritical power cycles.

Flash and binary systems are useful in large power plants having capacity in excess of $50 \mathrm{MWe}$. They require complexes of multiple-we11 field development and extensive networks of gathering lines. Innovative conversion systems are under development in which small power plants, in sizes of 1 to $15 \mathrm{MWe}$, may be installed at individual wells. These systems may involve a total flow concept in which both the thermal and kinetic energy of the geofluid is used for production of electricity. One of these is the impulse turbine, in which the thermal energy is converted to kinetic energy through a converging-diverging nozzle, and the high-velocity output drives a hydraulic impulse turbine operated at low pack pressure. Calculations indicate that a large unit (e.g., 220 MWe) might be feasible for the Salton Sea geothermal brines, which contain as much as $230,000 \mathrm{ppm}$ total dissolved solids. The material handling problems of such brines are indeed enormous, but the dissolved solids may also represent a source of valuable minerals, such as lead, manganese, and copper, if they can be processed economically. 
Another total-flow concept is the helical rotary screw expander which expands the vapor from hot saturated liquids by continuous pressure reduction in the expanding screw, in essence creating an infinite series of flashing stages. A small $62.5 \mathrm{kV}$ prototype model was tested successfully with moderate salinity geofluids with indications that it can accept the total flow of untreated brines. Still another concept is the bladeless turbine, in which a series of closely-spaced disks are rotated by viscous drag exerted by geofluids introduced by a nozzle. The device seems simple and self-cleaning, but the overall efficiency may be smal1.

Increased extraction efficiency represents a major means to stimulate geothermal energy production, especially for non-hydrothermal reservoir systems. Calculations show that hot-water reservoirs contain a larger amount of available energy than steam-filled reservoirs under the same reservoir conditions because of the much larger mass of water; but in either system, the heat contained in the rock formation is much larger than the heat in the fluids. Thus recovery of the formation heat would be of major economic significance. Extraction of formation heat must be a non-isothermal process, which can be achieved either by flashing geothermal liquids to steam within the formation or by recyc1ing colder fluids back into the formation. Laboratory investigations and theoretical calculations of reservoir models are underway to determine the extent of heat extraction from fractured reservoir formations. The natural extraction efficiency of energy from impermeable hot dry rock formations is extremely small. And yet hot dry rock in the upper $10 \mathrm{~km}$ of the earth's crust represents a major potential resource of 
geotherma1 energy. The volumetric energy extractable from hot dry rock, calculated for average expected properties and possible technical extraction efficients, is of the order of $1.2 \times 10^{9} \mathrm{kWh} / \mathrm{km}^{3}$ of fractured rock, equivalent to a volumetric power extraction of $1.4 \mathrm{MW} / \mathrm{km}^{3}$ for one century. The technical challenge is the ability to fracture such volumes of hot rock massives and achieve an extraction efficiency of the order of 10 percent.

Fracture stimulation methods are useful for many types of geotherma1 reservoirs. In vapor-dominated systems, stimulation may restore declining pressure or connect dry holes in commercial steam fields to producing sections. In liquid-dominated systems lacking sufficient productivity for economic power generation, fracture stimulation may provide larger wellbore diameter for increased flow rate, greater surface area for heat transfer, or restore porosity or permeability around wells having deposited silica, calcite, or other precipitated minerals. In dry geothermal systems, stimulation is needed to provide large fracture volumes for heat transfer to an artificial convective extraction system.

Several fracturing methods are under study; these include hydraulic fracturing, thermal stressing, and chemical and nuclear explosive fracturing. Hydraulic and explosive fracturing methods have already proven successful in stimulation of natural gas reservoirs.

Experiments to evaluate the potential for hydraulic and thermal stress fracturing for recovery of geothermal energy from hot dry rock formations are underway. In this concept a large diameter vertical crack is created hydraulically at the bottom of a boreholde in the geothermal formation. A second hole is drilled to intersect the upper part 
of the fracture, and a pump is used to initiate artificial heatextraction circulation. It is hoped that pumping can be discontinued if a natural convective circulation is achieved. The major technical problems are the attainment of a vertical crack of about $2 \mathrm{~km}$ diameter with sufficient fracture area, the creation of additional fracture area by thermal stress of cold water injection, and the ability to achieve a natural convective circulation without undue losses of water, especially in arid regions. Calculations indicate that under favorable conditions, the system might provide an average power of about $100 \mathrm{MW}$ (therma1) for twenty years.

\section{INSTITUTIONAL ASPECTS}

Although much remains to be done in locating adequate reserves and developing adequate technology to meet the goals for exploiting the Nation's geothermal resources, there is great confidence that these will be achieved. These problems involve advances in physical research and technology. Institutional problems, however, also exist. Such problems are complex; they involve public acceptance, vested interests, historical precedents, existing regulations from other resources, overlapping jurisdictions, and economic and financial factors. These problems are often more difficult to resolve than are engineering problems, and they may in the long run be the major constraints to an accelerated, but orderly development of geothermal resources. The solutions to many institutional problems may require broad public interaction, changes in regulations and legislation, and perhaps changes in traditional investment and marketing procedures. 
Economic factors affect all forms of energy supply; they involve total capital costs per installed power unit and operational costs per unit of energy production. For geothermal energy, both of these cost factors are strongly dependent on the specific characteristics of individual reservoirs and the size of the installed power plant units. Important capital costs include the investments for exploration, drilling and completion of wells, gathering lines and waste handing systems for all utilizations. For thermal energy applications, they also include the distribution system, and for electric power production, they include the power plants and the transmission network. The production costs are influenced by the cost of capital, operations and maintenance, and plant utilization factor. In the United States, additional costs must also be added for environmental pollution control.

Factual cost data for geothermal electric power production in the United States are available only for the Geysers field. The electric utility purchases steam from only one supplier, but has negotiated to purchase steam for future plants from additional suppliers. In the development of future geothermal power stations, an option exists for an integrated operation from exploration to power production in contrast to the traditional roles of an electric utility purchasing steam or hot water from an independent supplier. The general effect would be an increased investment cost per kilowatt hour of energy.

Data for costs of recently-constructed power plant units at the Geysers are sparse, but estimates for the original plants range from about $\$ 100$ to $\$ 150$ per $\mathrm{kW}$. Production costs were estimated at about $7 \mathrm{mill} / \mathrm{kWh}$ of which about $3.5 \mathrm{mill} / \mathrm{kWh}$ was the price of the purchased steam. These estimates included a cost of $0.5 \mathrm{mill} / \mathrm{kWh}$ for injection 
of water condensate as a disposal method. With escalation of drilling, construction, and envirommental reporting costs over the past few years, these cost values are not useful for estimating costs of new facilities, especially for reservoirs which do not produce dry steam. Recent estimates indicate installation costs may range from $\$ 500$ to $\$ 700$ per $\mathrm{kW}$ and operating costs for binary conversion systems of the order of 20 to $40 \mathrm{mill} / \mathrm{kWh}$. These costs, of course, are hypothetical, and more precise costs will be generated as other major reservoirs and plants are deve1oped and operated. A large uncertainty in the total cost is the fixed exploration cost for the resource, which is independent of plant capacity, and the average drilling costs of the production, dry, and injection we11s. Computer models to evaluate the relative importance of these resource and utilization costs are under development.

Because of large uncertainties in the technical costs of exploration and drilling, conversion efficients, and stimulation techniques, and because of the rapid escalation rate of these costs, it is difficult not only to estimate costs on an absolute basis, but even to compare costs of other forms of electric power generation. Besides the costs affected by these technical factors, other factors more social in nature must be considered. Among these are public acceptance and government stimulus for accelerating the development of geothermal energy in relation to other energy sources, the interpretation of compliance with the National Environmental Protection Act of 1969, and the availability of investment capital for development of geothermal resources and electric and thermal power plants. These socio-economic factors may require much public and government deliberation before general philosophies are widely accepted in practice. 
Although geothermal energy is considered to be one of the least polluting of the many forms of energy available, it should be assumed that the public will insist that the environmental impact of producing geothermal energy in all of its natural and stimulated forms, be thoroughly investigated in accordance with NEPA and any additional requirements under state and local legislation. Furthermore, in addition to environmental impact, it is also evident that assessment will be required of the operational aspects of the various types of resources which affect personnel safety and plant maintenance.

In the evaluation of a benefit-risk analysis, geothermal energy is expected to compare favorably with respect to other energy resources, especially when viewed over the entire fuel cycle. Since geothermal energy must be utilized or converted in the vicinity of the resource, the entire "fuel cycle" from reservolr to transmission is located at one site. This is in contrast with material fuels in which the cycle involves mining, storage, refining, transportation, reprocessing, and waste disposal, many or all of these at different locations. Furthermore, increased utilization of geothermal energy may result in a correspondingly reduced demand for material fuels in short supply, such as natural gas, oil, coal, and uranium. And still further, geothermal fluids may provide byproduct sources of water with reduced demand for cooling water.

Geothermal energy, nevertheless, has its array of potentially deleterious environmental impacts. A list of potential environmental impacts is given in Table 7. A review of the more important ones has recently been completed in a workshop sponsored by the National Science 


\section{TABLE 7}

ENIRONMETTAL IMPACTS OF GEOTHEPMAL PONER PRODUCTIOH-

\begin{tabular}{|c|}
\hline$\angle A N D$ \\
\hline $\begin{array}{l}\text { LAND UTILIZATION } \\
22 \mathrm{kM}^{2} / 100 \mathrm{MN}\end{array}$ \\
\hline $\begin{array}{l}\text { DRILLING OPERATIONS } \\
\text { 2O WELS } / \mathrm{kM}^{2}\end{array}$ \\
\hline $\begin{array}{l}\text { POWER PLANT CONSTRUCTION } \\
1 \text { PLANT/100 MN }\end{array}$ \\
\hline $\begin{array}{l}\text { SteAM GATHERING LiNeS } \\
\sim 0.2 \mathrm{~kW} 100 \mathrm{MW}\end{array}$ \\
\hline $\begin{array}{l}\text { CONDENSATE REINUECTION } \\
\text { LiNES AND PUMPS }\end{array}$ \\
\hline $\begin{array}{l}\text { POTENTIAL FOR } \\
\text { LAND SUBSIDENCE } \\
\text { SEISMIC ACTIVITT }\end{array}$ \\
\hline
\end{tabular}

\begin{tabular}{l} 
W A TER \\
\hline DisPOSAL OF \\
DRILING FLUIDS \\
NEED FOR SUPPLEMENTARY \\
COOLING WATER \\
BUILD-UP OF \\
SALT CONCENTRATIONS \\
DISPOSAL OF \\
CONDENSOR COOLING WATER \\
STEAM CONDENSATE \\
?3.5 MGPD/100 MW \\
POTENIIAL MINERAL AND \\
THERMAL POUUTION OF \\
FRESH SURFACE WATERS
\end{tabular} A I R ReLEASE of Steam AND OTHER GASES DURING DRILLING and TeSting
PbISE POLUTION
RELEASE OF $\mathrm{H}_{2} \mathrm{~S}$ AND OTHER NON-CONDENSABLE GASES
Potential Changes in MiCROMETEOROLOGY
Potential for WeLL BLowOUT THERMAL POLUTION OF SH SURFACE WATERS 
Foundation (see [7] in Bibliography) as the basis for a program to support research for baseline data and technology for monitoring potential impacts and controlling actual hazards. The major impacts include gaseous emissions, 1iquid waste disposal, and geophysical effects such as seismicity and subsidence. Other concerns involve thermal releases, surface water contamination, land use planning, cooling water consumption, and visual and noise pollution.

An array of legal problems associated with geothermal resource development also exists. These have been reviewed in another workshop Eponsored by the National Science Foundation (see [8] in Bibliography).

The legal problems of geothermal resources begin with resource definition, which varies from state to state. For example, in California geothermal resources are defined as "the natural heat of the earth, the energy--which may be extracted from naturally heated fluids-but excluding oil, hydrocarbon gas or other hydrocarbon substances." This definition leaves open the question whether geothermal resources are legally defined as water, mineral, or gas resources, and results in large uncertainty with respect to Federal, state, and local jurisdictions. On the other hand, the State of Hawail considers geothermal resources as minerals, whereas the State of Wyoming has declared them water resources. As water resources, they would be subject to the very complicated set of state laws concerning water rights and regulation. As minerals, they would be subject to mining laws and such problems as ownership, depletion allowances, and write-off of intangible drilling costs. Geothermal resources have already been classified in court decisions in different ways. In one case a U.S. District Court in San Francisco treated the 
Geysers geothermal resource as "nothing more than superheated water" and therefore not a mineral, but in another case, the resource was held to be a gas within the meaning of the Internal Revenue Code provisions for depletion allowance and intangible drilling costs.

Ownership rights is a1so a serious institutional problem. The Federal government has given some 35 million acres of land to the homesteaders, States, and raflroads, but generally reserved the mineral rights to the Federal government. However some State grants included mineral rights and thus many problems exist in the ownership aspects of Federal and State lands under the leasing of these lands for geothermal energy development. Land utilization for geothermal resources also comes under the jurisdiction of local governments, except for resources on State or Federal lands.

Other institutional questions at the State level include the acreage level for commercial development, the need for long-range financial and land use planning, and the overlapping of State regulatory agencies with each other and with jurisdictions of local governments for permits, 1icences, taxation, and especially environmental control. The latter may be affected at the Federal, State, regional, county, or city government levels. For example, in some areas, authority may be divided between such agencies as a Regional Land Development Commission and a County Air Pollution Control Board.

The Institutional aspects of licensing and regulation of power plants is very complicated; they cover the spectrum from Federal to local jurisdictions. Regulations already exist with respect to the exploration, drilling and operation of water and mineral wells in all states. The 
extension to geothermal wells should be relatively simple. Yet the need to satisfy the provisions of NEPA and any specific State environmental requirements may make geothermal resource development a slow process. For example, in Callfornia, the State Lands Commission, before it can lease any lands under its jurisdictions, must make a finding at a public meeting that the lease w111 not have significant detrimental environmental effect and must prepare an environmental impact report available to the legislature and the public. The corresponding problems of environmental impact from geothermal resources in private lands are not yet fully resolved.

Once the field is developed to the point where a utility contracts to purchase the resource and construct a power plant, other regulatory agencies come Into the picture, such as the Federal Power Commission and corresponding state and local agencies. Site selection and environmental analysis criteria are becoming of major importance in power plant licensing for all types of energy resources and their effect on geothermal energy development will probably be determined by solution of these problems on a generic basis, rather than specifically for geothermal energy alone.

Institutional problems thus involve many social, legal, environmental, and economic questions. The problems become more complex for land use planning when geothermal resources span Federa1, state, and private lands. They involve capital investment problems for geothermal development which may be considered to be high-risk and involve long-delay times until they become income producing. They involve inter-industry arrangements when multi or total utilization is needed to support economic 
development of electric power generation, thermal power heating, desalination and mineral recovery. And they involve multi-government arrangements in the realms of regulation, licensing, and environmental control.

\section{NATIONAL GEOTHERMAL PROGRAM}

Although significant growth of the one natural steam field in the United States has occurred since 1960, it has become apparent that a major national effort of Industrial development supported by Federal stimulation is needed to develop the potential of geothermal resources in its several forms as an alternate energy source. Early efforts to achieve a coordinated Federal program for the support of research and development were undertaken by an informal Interagency Panel for Geothermal Energy Research. From these efforts evolved a 5-year program whose objective was the rapid development of a viable geothermal industry for the utilization of geothermal resources for electric power production and other products. The goals and plans for this program were prepared by the Interagency Task Force on Geothermal Energy under direction of the National Science Foundation in the Federal Energy Administration "Project Independence Blueprint" (see [9] in Bibliography). The task force evaluated two alternate strategies. The first was "business-as-usual" which assumed continuation of current policies affecting levels of geothermal production. The second was "accelerated demand" which assumed specific changes that would result in a more rapid expansion of potential production.

The task force estimated that under the "business-as-usua1" assumptions, electric power capacity could reach 4000 MWe by 1985 and perhaps 59,000 MWe by 1990. The corresponding numbers for the "accelerated 
demand" assumptions were 20,000 to 30,000 MWe by 1985 and 100,000 MWe by 1990. These latter values were adopted as the primary goal of a proposed National Geothermal Energy Research Program, which was directed towards (1) providing the necessary technological advances to improve the economics of geothermal power production, (2) expanding the knowledge of recoverable resources of geothermal energy, and (3) providing carefully researched policy options to assist in resolving environmental, legal, and institutional problems.

The major research funding agencies which contributed to the task force program were the Atomic Energy Commission, the Department of the Interior, and the National Science Foundation which served as lead Federal Agency. The status of the research carrled out under support from these agencies is described in the proceedings of a conference on research for the development of geothermal energy resources (see [10] in Bibliography).

During 1974, two acts of Congress resulted in a marked change in direction for the national development of geothermal energy. The first was PL 93-410, the Geothermal Energy Research, Development, and Demonstration Act of 1974, which established a Geothermal Energy Coordination and Management Project. The Project was given responsibility for the management and coordination of a national geothermal development program which included efforts to: (1) determine and evaluate the geothermal resources of the United States; (2) support the necessary research and development for exploration, extraction, and utiliżation technologies; (3) provide demonstration of appropriate technologies; and (4) organize and implement the loan guarantee program authorized in Title II of the Act. 
The second law was PL 93-438, the Energy Reorganization Act of 1974, which established the Energy Research and Development Administration, ERDA, with responsibility as lead Federal agency for activities related to RED of all energy sources. The Act abolished the AEC and transferred the geothermal development function of the AEC and NSF to ERDA. On January 19, 1975, ERDA assumed responsibility for the national program of geothermal energy development. It has also assumed direction of the Geothermal Energy Coordination and Management Project which has completed the Final Report required by PL 93-410 (see [11]). In addition, ERDA, in response to Congressional requirements and internal needs, prepared a comprehensive $R, D \& D$ plan (see [12]) for developing energy technology options. The geothermal section of the plan built upon the predecessor plans of the Task Force for Geothermal Energy and the Geothermal Project and has based the goal for the national program on the rational given in Volume 2 of the Plan.

The objectives being considered in the ERDA program for geothermal energy include methods to stimulate the industrial development of indigenous hydrothermal resources to provide the Nation with 10,000 to 15,000 MW of electric power and thermal energy during the 1985 to 1990 period and to develop new and improved technologies for cost-effective and environmentally-acceptable utilization of all types of geothermal resources as a long-term alternate source of energy.

The strategy of the program which might accomplish such objectives would be to accelerate industrial development of the nation's geothermal resources by (1) coordinating efforts for exploration and assessment of geothermal resources necessary to establish reserves by 1978-1980 which can support production of 20,000 to $30,000 \mathrm{MW}$ of power, 
(2) demonstrating near-term and advanced technologies needed to utilize many types of geothermal resources in a cost-effective and environmentallyacceptable manner, and (3) fostering rapid development of a viable geothermal industry by appropriate incentives, timely reduction of institutional impediments, and direct participation of the private sector in development and demonstration of geothermal energy technology.

A1though ERDA assumes overall responsibility for effective management and coordination of Federal geothermal activities, the scope of the Federal program includes the efforts of many Federal agencies. The Geothermal Steam Act of 1970 authorized the Department of the Interior to lease Federal lands for geothermal resource exploration, development, and production of energy and useful byproducts (such as methane, desalinated water, and valuable minerals). The leasing program is conducted by the Bureau of Land Management which is responsible for selecting lands for lease and holding lease sales and the U.S. Geological Survey which classifies the lands by appraised value.

The U.S. Geological Survey's geothermal research program is focused on the characterization and description of the nature and extent of the geothermal resources of the United States. The output of the U.S. Geological Survey's program is the determination of the magnitude of the geothermal resource base on a national and regional basis. The Survey's program includes development of exploration technology, methodology for estimating energy potential of geothermal systems, environmental effects of geofluid withdrawal, and geochemical aspects of reservoir permeability.

Some of the problems that have retarded the delineation of the Nation's geothermal resources through the leasing of public lands include 
the lack of reliable information regarding suitable resources, even on lands classified as KGRAs, insufficient requirements for early exploration and development of leased lands, and legal problems involving ownership and control of use of geothermal resources. Under a national program, coordinated effort by ERDA and the Department of the Interior would help to accelerate the establishment of geothermal reserves by the resource industries. Potential actions include (1) accelerated estimation by the U.S. Geological Survey of the available resources by geologic type, (2) improved technology for resource exploration and assessment and for reservoir evaluation, (3) easing of leasing impediments by better methods for designating KGRAs and establishing minimum acceptable bids, (4) incentives for early development of leased lands, and (5) recomendations for legislation to resolve legal uncertainties pertaining to geothermal resources.

The second part of the strategy for the Federal program would center on ERDA efforts for demonstration of near-term and advanced systems for resource utilization, development of supporting research and technology, and execution of the Federal loan guarantee program. Demonstrations of utilization technology could occur as (1) commercial-scale demonstration plants to provide the public sector with operational experience with full-scale electric power plants capable of generating energy at design production cost under pertinent environmental and institutional conditions, (2) pilot-plant facilities to prove technical feasibility, provide preliminary economic data, and provide capability for testing new and improved extraction and conversion systems for electric power production, and (3) field test facilities to improve 
reservoir assessment technology, evaluate reservoir characteristics and performance, test and evaluate energy extraction and conversion components and processes, evaluate material compatibility with geothermal fluids, and test environmental control technologies. A supporting research and development program could provide for development of hardware systems, components, processes, and control techniques for installation in the demonstration facilities and field testing of reservoir evaluation technologies for the range of resource types. Supporting research and deve1opment program could also provide advanced research and technology to the geothermal industry and its supplier and support industries for improved productivity and utilization.

Implementation of the Loan Guarantee program should be coordinated with the Bureau of Land Management's geothermal leasing program and ERDA's research, development, and demonstration program. The program could involve venture capital companies, reservoir developers, and lease holders to maximize the impact of the loan program in stimulating early development of commercial electric and thermal power facilities. The Loan Guarantee program might be used primarily for income-producing projects, such as field development and power-plant construction. Smaller industrial firms could benefit from guaranteed loans by gaining access to necessary private capital. Regulations and procedures governing the implementation of the loan guarantee program are currently being drafted in coordination with other Federal agencles, such as the Small Business Administration and the Economic Development Administration. Approved regulations and operating procedures setting forth specific information requirements to be met by the applicant and criteria governing the approval process should be widely publicized as early as possible. 
The third part of the strategy of the Federal program would involve several Federal agencies, notably the National Science Foundation, involved in assessing environmental, legal, and institutional problems of advanced energy technology under its RANN program, the Environmental Protection Agency, involved in environmental emission standards, monitoring, and control technologies, and the Federal Energy Administration, involved in institutional aspects of the national energy situation. With the mutual efforts of the Federal program and the geothermal industry, the attainment of the National electric and thermal energy goals for geothermal resources could add a significant alternate energy source to the national economy before the end of the present century. 


\section{BIBLIOGRAPHY}

1. Proceedings, United Nations Symposium on the Development and Utilization of Geothermal Resources, Geothermics, Special Issue No. 2, 2 volumes, 1970.

2. H. C. H. Armstead, ed., "Geothermal Energy: Review of Research and Development," Earth Science Serles No. 12 (UNESCO, Paris, 1973).

3. P. Kruger and C. Otte, eds., "Geothermal Energy: Resources, Production, Stimulation" (Stanford University Press, Stanford, 1973).

4. Scientific Council for Geothermal Energy, USSR Academy of Sciences, "Geothermal Investigation and Utilization of the Heat of the Earth" (Nauka, Moscow, 1966).

5. Scientific Council for Geothermal Energy, USSR Academy of Sciences, "Study and Utilization of the Deep Heat of the Earth" (Nauka, Moscow, 1973).

6. Informatics, Inc., Recent Soviet Investigations in Geothermy ARPA-1622-3, May, 1972, and Soviet Geothermal Electric Power Engineering, ARPA-1622-3, December, 1972.

7. Proceedings, Workshop on Environmental Aspects of Geothermal Resources Development, National Science Foundation Report No. AER 75-06872, 1974.

8. Proceedings, Conference on Geothermal Energy and the Law, National Science Foundation Report No. NSF-RA-S-75-003, 1975.

9. Federal Energy Administration, Project Independence Blueprint, Final Task Force Report, Geothermal Energy, November, 1974.

10. Proceedings, Conference on Research for the Development of Geothermal Energy Resources, National Science Foundation Report No. NSE-RA-N-74- 159, 1974.

11. Energy Research and Development Administration, Definition Report: Geotherma1 Energy Research, Development and Demonstration Program, ERDA- 86, October, 1975.

12. Energy Research and Development Administration, A National Plan for Energy Research, Development and Demonstration: Creating Energy Choices for the Future, ERDA-48, 2 volumes, June, 1975. 